\title{
NILAI-NILAI KEARIFAN LOKAL SASAK DALAM PERSEKOLAHAN DI LOMBOK TIMUR
}

Oleh:

Habibudin

Universitas Hamzanwadi

Email: Habibudin@gmail.com

\begin{abstract}
Abstrak
Nilai-nilai kearifan lokal Sasak dapat berperan untuk membangun perdamaian di tengah kehidupan masyarakat. Namun sayangnya nilainilai tersebut hanya hidup dalam alam pikiran, belum berperan dalam membentuk sikap dan perilaku damai. Penelitian ini bertujuan menganalisis nilai-nilai perdamaian dalam nilai-nilai kearifan lokal etnis Sasak pada kehidupan di sekolah. Penelitian ini menggunakan paradigma kualitatif dengan jenis grounded theory. Pengumpulan data melalui observasi, wawancara mendalam, dan dokumentasi. Analisis data menggunakan model interaktif, yakni pengumpulan data, reduksi data, penyajian data, pengambilan simpulan. Temuan penelitian menunjukkan nilai-nilai perdamaian yang terkandung dalam nilai-nilai kearifan lokal etnis Sasak terdiri atas 10 (sepuluh) nilai, yakni saling ajinang (saling meng-hormati, menghargai), tertip-terpi (tertib-teratur), teguq (tanggung jawab), solah perateq, (baik hati), soloh (toleransi, cinta damai), tetes (partisipatif), saling saduq (saling percaya), besemeton (persaudaraan), ra’i (empati), dan bedadayan (kerja sama).

Kata Kunci: kearifan lokal, nilai perdamaian, Sasak
\end{abstract}

\begin{abstract}
The values of Sasak local wisdom have positive role in order to building of peace in the midst of people's. Unfortunately these values only live in the mind, have not a role in the building of peaceful attitudes and behavior. This study aims to analyze the values of peace in the values of Sasak ethnic local wisdom on school life. This study uses a qualitative paradigm with a type of grounded theory. Data collection through observation, indepth interviews, and documentation. Data analysis uses an interactive model, consist of data collection, data reduction, data presentation, and drawing conclusions. The research findings show that the values of peace contained in the values of Sasak ethnic local wisdom consist of 10 values, namely saling-ajinang (respecting each other, respecting), tertip-terpi (orderly), teguq (responsibility), solah perateq, (kindhearted), soloh (tolerance, love for peace), tetes (participatory), saling saduq (mutual trust), besemeton (brotherhood), ra'i (empathy), and bedadayan (cooperation).

Keyword: local wisdom, values of peacefull, Sasak
\end{abstract}




\section{Pendahuluan}

Nusa Tenggara Barat memiliki sejarah yang panjang dengan masalah konflik, seperti konflik pembangunan Bandara Internasional Lombok (BIL) di Lombok Tengah, disebabkan oleh masalah pembebasan lahan miliki petani yang dilaksanakan oleh pihak Angkasa Pura. Konflik lainnya adalah antara PNS dengan Pemerintah Daerah Lombok Timur penyebabnya kebijakan pembayaran zakat bagi PNS kepada Badan Amil Zakat Daerah Lombok Timur melalui Perda No. 9 Tahun 2002 (Suprapto, 2013). Konflik terbaru tahun 2018 terkait penolakan pergantian nama Bandara Internasional Lombok menjadi Zainuddin Abdul Madjid International Airport (ZAMIA). Fenomena tersebut merupakan serangkaian konflik yang menyebabkan melemahnya solidaritas dan kebersamaan di dalam masyarakat semakin menipis.

Konflik kesejarahan, sosial, dan budaya di Cakranegara Kota Mataram dipicu oleh asal-usul, perkembangan perkampungan, dan penghayatan filosofi hidup yang makin memudar dan menghilang, khususnya di kalangan generasi muda, meskipun secara geografis mereka tinggal berdampingan. Kondisi tersebut memicu munculnya persaingan dan solidaritas komunal sehingga yang tampak adalah potensi konflik, sedangkan potensi integrasi makin tenggelam dan sulit muncul (Nasir, 2005). Konflik keagamaan, seperti Islam dengan agama lain tahun 1997 komunitas Kristen di Praya Lombok Tengah terganggu akibat pembakaran rumah ibadah mereka, tahun 1980-an hubungan Islam dan Hindu akibat kesalahpahaman terjadi mesiat (perang) di Taliwang Cakranegara Kota Mataram karena pembangunan tempat ibadah yang berdekatan. Pada tahun 2000 terjadi kesalahpahaman tentang ekspresi keagamaan antara Hindu dan Islam dalam melangsungkan ibadah nyepi dan ziarahan.

Konflik keagamaan lain, seperti Ahmadiyah dengan warga masyarakat di Lombok Timur dan Lombok Barat, Salafiyah dan warga masyarakat di Lombok Barat, Lombok Tengah, dan Lombok Timur, tarekat Siratal Mustaqim dan warga masyarakat Grunung Praya di 
Lombok Tengah, kasus 171 (kerusuhan 17 Januari 2000) di Kota Mataram, dan konflik NW Pancor dan NW Anjani di Lombok Timur (Suprapto, 2013, Hamdi, 2014). Konflik antarkampung, seperti Karang Genteng dan Patemon, Karang Genteng dan Pagutan Presak di Kota Mataram yang terus berulang sejak tahun 1988. Konflik antarkampung lainnya, seperti Ketara dan Penujak, Ketara dan Batujai, Ketara dan Sengkol, Ketara dan Tenandon di Lombok Tengah penyebabnya dipicu oleh perkelahian remaja diikuti perkelahian antarkampung (Suprapto, 2013). Konflik antarkampung juga terjadi akibat pemekaran wilayah di Desa Gerung Kecamatan Suralaga Lombok Timur.

Konflik lingkungan dan pertanahan disebabkan oleh: (a) aturan hukum kurang jelas, (b) pemahaman masyarakat terhadap hukum masalah warisan, jual beli, sewa menyewa, dan lain-lain memunculkan sengketa, (c) sumber-sumber produksi masyarakat berupa tanah pertanian makin sempit sementara manusianya makin banyak, (d) kurangnya komunikasi antara salah satu pihak yang merasa dirugikan mengakibatkan munculnya konflik pertanahan, dan (e) masyarakat tertentu masih kuat mempertahanakan adat istiadat sehingga memicu sengketa tanah (Asmara, Arba \& Maladi, 2010). Tahun 2018 konflik pengelolaan tanah ulayat atau tanah adat antara Pemerintah Daerah Lombok Timur dan warga masyarakat di Kecamatan Suela dan Sembalun Lombok Timur.

Beberapa tahun terakhir masyarakat etnis Sasak mengalami gejolak social yang hampir-hampir mengguncangkan masyarakat Lombok. Gejolak sosial tersebut berupa konflik politik dan ekonomi, kesejarahan, sosial, dan budaya, keagamaan, antarkampung, dan lingkungan. Budaya damai merupa-kan bagian dari perilaku, perbuatan, dan cara hidup yang didasarkan atas penolakan kekerasan terhadap hak asasi manusia, kebebasan, pemahaman, toleransi dan solidaritas, saling berbagi, partisipasi, dan kesempatan yang sama bagi perempuan) sehingga tercipta suasana yang tenang dan berkeadilan (UNESCO, 2001; Reardon, 2001). Membangun perdamaian merupakan 
suatu proses transformatif yang memerlukan dukungan dari semua pihak secara terus menerus dan berkelanjutan (Turay, 2008; Meziro, 1997).

Masalah utama membangun perdamaian pada dasarnya bersumber dari tiga hal, yaitu akar-akar struktural dan kultural konflik di masa lalu (kesenjangan, ketidakadilan, krisis kelembagaan) yang masih belum sepenuhnya teratasi, dampak konflik kekerasan di masa lalu terhadap kemerosotan kualitas hidup warga (kemiskinan, pengangguran, kesejateraan sosial, ekonomi, dan sebagainya), dan belum efektifnya implementasi perjanjian damai atau pembangunan perdamaian (Trijono, 2009). Pertanyaan mendasar, mungkinkah kearifan lokal etnis Sasak dapat dijadikan sumber membangun perdamaian? Jika itu mungkin, konteks yang bagaimana? Kalau ditelusuri berbagai literatur dalam kehidupan etnis Sasak ditemukan sumbangan kearifan lokal yang cukup signifikan dalam membangun perdamaian. Kearifan lokal tersebut telah diwariskan secara turun temurun melalui tradisi penyelesaian konflik secara damai. Tradisi tersebut dijadikan pedoman atau pengarah cara berpikir, perilaku, dan perbuatan seseorang atau warga dalam kehidupan sehari-hari untuk membangun suasana damai.

Beberapa penelitian mengenai kearifan lokal etnis Sasak yang telah dilakukan, seperti Syakur (2002) menyebutkan etnis Sasak mengenal tradisi sangkēp (musyawarah) dalam menyelesaikan suatu masalah (konflik) dan merumuskan segala sesuatu secara gotong-royong, seperti menghadapi perkawinan, kematian, pembangunan tempat ibadah, dan lain-lain. Suprapto (2013) mengungkap pola-pola penanganan konflik yang terjadi di Lombok dengan kearifan lokal, seperti melalui sēsēnggak (pribahasa, ungkapan bijak), pērtēke atau lēlakaq (pantun) sebagai bahan pengembangan resolusi konflik. Selain itu, tradisi yang masih dipraktikkan oleh masyarakat seperti begibung (makan bersama), adanya awig-awig (aturan-aturan adat) bagi upaya resolusi konflik sekaligus upaya membina perdamaian (peace building). Nasir, dkk, 
(2005) \& Tumanggor (2007) menyebutkan kearifan lokal etnis Sasak dalam membangun kebersamaan melalui tradisi saling jot (saling mengantar makanan), saling pēlangarin (saling melayat), saling ayoin (saling mengunjungi), saling ajinang (saling menghormati-menghargai). Tradisi demikian dipertegas oleh Budiasmoro (2014) mengenai kemampuan masyarakat mempertahankan nilai-nilai yang dimiliki mencerminkan kepribadian dan jati diri sebagai bentuk ekspresi identitas budaya mereka.

Realitasnya eksistensi kearifan lokal makin melemah ditandai kemerosotan moral di kalangan generasi muda berupa perselisihan dan pertengkaran secara individu dan kolektif, seperti tawuran antarpelajar dan antarkampung dalam bentuk pemukulan, penganiayaan, pengancaman, pelecehan, dan lain-lain yang sering dipicu oleh sebab-sebab sepele (Kartadinata, dkk, 2015). Hal tersebut berulang terjadi dengan berbagai sebab yang sulit ditemukan jalan keluarnya dan memuaskan pihak yang berkonflik (Lestari, dkk, 2017). Di Lombok Timur tahun 2016 terjadi 135 kasus kekerasan terhadap anak berupa pemukulan, penganiayaan, pemerkosaan, pelecehan, dan lain-lain. Tahun 2017 terjadi 121 kasus kekerasan berupa pemukulan, penganiayaan, pemerkosaan, pengancaman, pelecehan seksual, aborsi, dan lain-lain (DP2AP Lombok Timur, 2017/2018). Berangkat dari fenomena tersebut, perlu dilakukan penelitian untuk menjelaskan dan menganalisis nilainilai perdamaian dalam kearifan lokal etnis Sasak. Hal tersebut didasari oleh beberapa aspek yaitu: (1) nilai-nilai perdamaian yang terkandung dalam kearifan lokal etnis Sasak belum terungkap secara gamblang, (2) kearifan lokal etnis Sasak dapat menjadi sumber upaya membangun perdamaian, dan (3) etnis Sasak memiliki tradisi penyelesaian konflik maupun kekerasan secara damai.

\section{Metode Penelitian}

Metode Penelitian yang digunakan adalah penelitian kualitatif tidak menekankan pada generalisasi tetapi menekankan pada makna. 
Metode ini dianggap relevan karena data yang hendak digali adalah nilai-nilai yang abstrak sifatnya dan memerlukan pemaknaan. Maanen (1983: 9) menyatakan:

... the label qualitative methods has no precise meaning in any of the social sciences. It is a best an umbrella term covering an array of interpretative techniques which seek to describe, decode, translate, and otherwise come to terms with the meaning, not the frequency, of certain more or less naturally occurring phenomena in the social world.

Metode kualitatif tidak mempunyai arti yang persis dalam ilmu sosial. Metode ini merupakan istilah yang meliputi teknik interpretasi yang berusaha mendiskripsikan, mengkode, dan menerjemahkan atau istilah-istilah lain yang berusaha mencari makna dari fenomena. Pendekatan ini diarahkan pada latar dan individu secara holistik dan tidak meng-isolasinya dalam variabel atau hipotesis.

Teknik pengumpulan data melalui observasi, wawancara mendalam (indepth interview), dan dokumentasi. Analisis data menggunakan model interaktif dari Miles \& Huberman (1994), yakni pengumpulan data (data collection), reduksi data (data reduction); penyajian data (data display), mengambil kesimpulan (conclusions drawing/verification).

\section{Hasil Penelitian}

Nilai-nilai kearifan lokal etnis Sasak memiliki peran meningkatkan kualitas kesadaran dan pemahaman diri seseorang, warga, dan institusi sosial dalam menciptakan perdamaian hidup sehari-hari. Nilai-nilai tersebut dapat mengarahkan cara berpikir, perilaku, dan perbuatan seseorang untuk cinta damai. Peneliti menemukan 10 nilai kearifan lokal dalam masyarakat Sasak yang berpotensi menjadi sumber pokok dalam melakukan inkulkasi dan revitalisasi perdamaian di Lombok. 


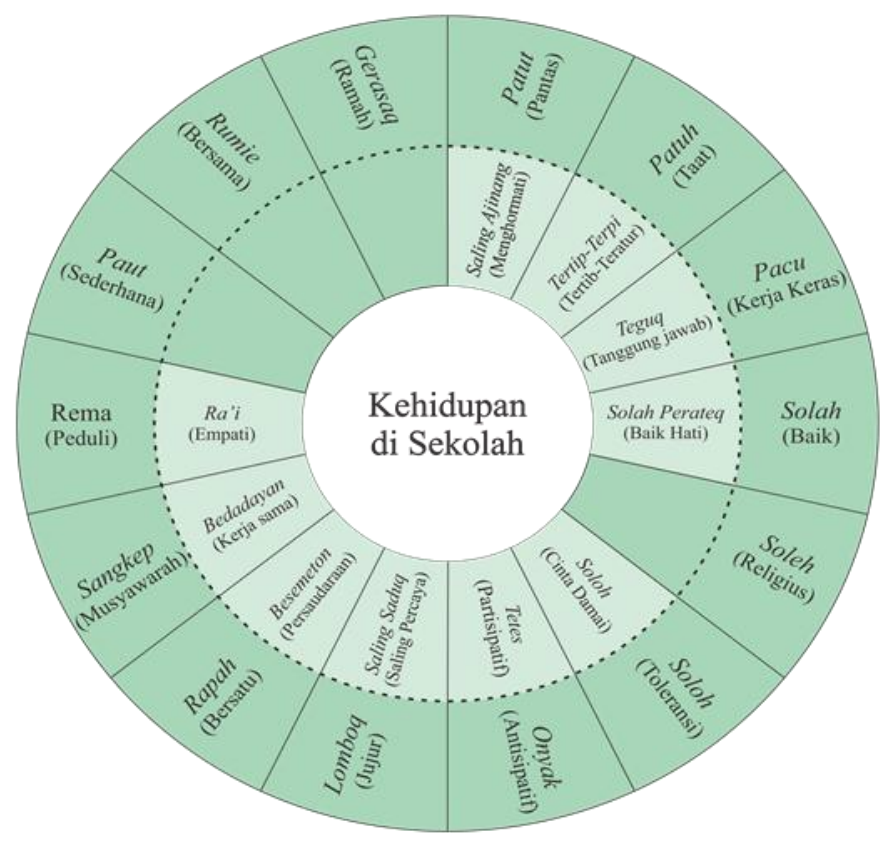

Gambar 1. Nilai-nilai Kearifan Lokal Sasak pada Sekolah di Lombok Timur

Nilai-nilai tersebut merupakan pedoman bagi masyarakat dalam kehidupan sehari-hari yang mendorong lahirnya perdamaian. Nilai-nilai tersebut membuktikan secara ideal adat istiadat etnis Sasak memberi bekal berupa nilai-nilai bagi kehidupan individual maupun sosial. Nilainilai tersebut dapat dijadikan media penyelesaian konflik dalam hidup untuk perdamaian. Terbangunnya perdamaian tampak dalam cerminan perilaku dan perbuatan seseorang melaksanakan nilai-nilai tersebut dengan harapan memiliki kepribadian luhur. Kepribadian tersebut seseorang harus memahami diri secara utuh atau dikenal taoq takaq (tahu tempat), taoq adat (tahu adat), dan taoq diriq (tahu diri) (Fathurrahman, 2017). Uraian berikut akan menjelaskan makna dari nilai-nilai kearifan lokal di sekolah sebagai berikut.

\section{1) Saling Ajinang}

Saling ajinang (saling menghormati-menghargai) terdapat dalam patut (baik, pantas) merupakan penghormatan dan penghargaan seseorang kepada orang lain tanpa memandang perbedaan etnis, agama, golongan, dan status sosialnya. Penghormatan dan pengharga- 
an tersebut juga dilakukan oleh orang yang lebih tua (guru) pada orang yang lebih muda (siswa), begitu juga sebaliknya. Saling menghargai memiliki tujuan personal, yaitu perubahan perilaku, pengembangan solidaritas, dan keterampilan bertindak (Reardon, 1999). Menghargai sebagai upaya menghargai diri sendiri, orang lain, dan lingkungan, memperlakukan orang lain seperti keinginan untuk dihargai, beradab, sopan, tidak menghina orang lain, dan tidak menilai orang lain sebelum mengenalnya dengan baik (Samani \& Hariyanto, 2012).

Saling ajinang dalam membangun perdamaian pada kehidupan di sekolah berhubungan dengan: (1) perilaku menghargai perbedaan fisik (seperti warna kulit, rambut, dan lain-lain) dan nonfisik (seperti etnis, agama, golongan, staus sosial, dan lain-lain). Melalui perilaku tersebut seseorang mampu menempatkan diri pada porsinya masing-masing dan menghargai perbedaan sehingga tidak terjadi konflik yang disebabkan perbedaan fisik dan nonfisik tersebut, (2) perilaku memberi penghargaan sebagai upaya mencegah konflik. Konflik sering terjadi disebabkan ketidakmampuan seseorang mengendalikan diri dan menjaga perasaan orang lain. Saling ajinang didasari kemampuan seseorang mengendalikan diri, seperti menekan ego pribadi untuk tidak terlibat konflik di dalam maupun di luar sekolah.

2) Têrtip-Terpi

Tertip-terpi (tertib-teratur) terdapat dalam nilai patuh (taat) merupakan suatu proses pembelajaran diri seseorang untuk memahami titi kramã (cara bermasyarakat) berupa awig-awig (aturan adat) sebagai upaya menciptakan keteraturan dan mewujudkan perdamaian hidup sehari-hari. Hasibuan (2007) menjelaskan tertib-teratur adalah kesadaran dan kesediaan seseorang mentaati semua aturan-aturan dan norma-norma sosial yang berlaku. Kesadaran adalah sikap seseorang yang secara sukarela menaati semua aturan dan sadar akan tugas dan tanggung jawabnya, dan mematuhi atau mengerjakan semua tugasnya dengan baik bukan atas paksaan 
Tertip-terpi pada diri seseorang dilihat dari kesediaannya melaksanakan aturan-aturan, seperti tata tertib, etika siswa, dan perintah-larangan yang berlaku. Tertip-terpi dalam perilaku dan perbuatan menentukan proses membangun perdamaian dan dipengaruhi oleh pelanggaran aturan, seperti nganut (sekehendak hati), bêngkeng (melawan), dan lain-lain. Tertip-terpi sebagai nilai perdamaian dimaknai perilaku dan perbuatan taat melaksanakan aturan, perintah, dan larangan yang berlaku di sekolah. Perilaku dan perbuatan tersebut terkait kesediaan seseorang menggunakan waktu dengan baik, melaksanakan tugas, kewajiban, dan mewujudkan cita-cita seseorang. Perilaku dan perbuatan tertip-têrpi seseorang dilandasi kesadaran menjalankan aturan-aturan untuk menciptakan kedamaian dalam hidup dengan bersama menjaga kenyamanan, keamanan, dan ketenangan di sekolah. Kepatuhan merupakan modal dasar bagi suku bangsa Sasak untuk membangun masyarakat yang tertib dan damai.

\section{3) Teguq}

Teguq (tanggung jawab) terkandung dalam nilai pacu (kerja keras). Têguq dimaknai kewajiban seseorang melaksanakan tugas-tugas tertentu yang diembannya, seperti kewajiban pada diri sendiri, sesama, lingkungan, dan kehidupan berbangsa, serta keyakinan. Mustari (2011) menyatakan tanggung jawab adalah perilaku seseorang untuk melaksanakan tugas dan kewajiban sebagaimana seharusnya dilakukan terhadap diri sendiri, masyarakat, lingkungan (seperti alam, sosial, dan budaya), negara, dan Tuhan.

Samani \& Hariyanto (2012) memaknai tanggung jawab sebagai cara mengetahui dan melaksanakan apa yang harus dilakukan sebagaimana diharapkan orang lain. Tanggung jawab dikelompokkan menjadi dua, yaitu: (1) tanggung jawab terhadap diri sendiri, seseorang harus bertanggung jawab terhadap akal pikiran yang dimiliki, ilmu, raga, waktu, dan lain-lain pada kehidupan, dan (2) tanggung jawab pada orang lain (lingkungan sosial). Manusia sebagai mahluk sosial 
membutuhkan orang lain dalam hidup untuk mengembangkan diri, atau dengan kata lain manusia memiliki kewajiban moral terhadap lingkungannya, kewajiban ini erat kaitannya dengan eksistensi seseorang sebagai bagian dari warga masyarakat.

Têguq dalam membangun perdamaian dalam kehidupan di sekolah dimaknai sebagai: (1) kewajiban seseorang melaksanakan tugas tertentu yang melekat dalam dirinya. Têguq tersebut terkait kewajiban pada diri sendiri, lingkungan hidup, sesama, kehidupan berbangsa, dan pada keyakinan, dan (2) têguq berkaitan dengan berbuat maksimal dalam segala sesuatu, seperti bila diterapkan dalam belajar untuk menyelesaikan tugas atau kewajiban lain. Seseorang memahami têguq akan konsekuen dan memiliki komitmen melaksanakan tugaskewajiban yang dirinya dengan baik sesuai tujuan yang hendak dicapai. 4) Solah Perateq

Solah perateq (baik hati, nirkekerasan) dalam kehidupan di sekolah diidentikkan dengan nirkekerasan merupakan nilai yang terkandung dalam solah (baik). Seseorang memiliki solah pêratêq harus menunjukkan empat hal, yaitu menghormati individu, menyayangi sesama, persahabatan, dan menjaga keberagaman. Nimer (2010) menyampaikan tentang nirkekerasan memiliki arti tidak membunuh, bila dilihat lebih jauh yaitu seseorang tidak boleh menyerang orang lain dan tidak memendam pikiran jahat atau tidak memiliki belas kasihan pada orang lain. Nirkekerasan secara substansi memiliki makna yang sama dengan kontrol diri (self-control) sebagaimana disampaikan oleh Samani \& Hariyanto (2012) yaitu menolak keinginan yang jahat dan buruk, dan mengerjakan yang baik-baik.

Solah pêratêq dalam membangun perdamaian dalam kehidupan di sekolah memiliki makna: (1) perilaku menghormati kebebasan individu, artinya setiap individu memiliki kemampuan berbuat sesuai keinginannya. Kebebasan individu tersebut seperti berteman dengan siapa saja, menghormati hak orang, dan kecaman pada diri yang positif, (2) saling menyayangi, berupa perilaku tidak menghujat, tidak mencela, 
dan tidak mengejek. Bentuk kasih sayang tersebut, seperti mengakui hak orang lain dengan cara ate solah dan ate sakit, memberi perhatian, dan tidak membedakan perlakuan pada orang lain, (3) bersahabat, terkait perilaku membangun kerja sama. Persahabatan dibangun dengan tidak melakukan pelecehan (fisik dan nonfisik), dan (4) perilaku menjaga keberagaman hidup, dilakukan oleh seseorang yang menyadari manusia terdiri dari latar belakang. Menjaga keberagaman dilakukan dengan jamaq-jamaq (apa adanya) dan memiliki ilaq/wirang (rasa malu) melakukan perbuatan tak bertanggung jawab.

5) Soloh

Soloh (cinta damai, toleransi) merupakan nilai utama dalam kehidupan di sekolah untuk menghadapi keberagaman. Soloh dimaksud cara berpikir, berperilaku, dan berbuat dalam menyikapi perbedaan secara positif. Soloh mendorong seseorang untuk berguna bagi orang lain dengan bersama-sama menciptakan kenyamanan. Khalikin \& Fathuri (2016) menyampaikan toleransi adalah kesediaan menghargai, menghormati, dan menerima keberadaan umat beragama lain yang diaktualkan dalam sikap dan perilaku baik perorangan maupun kelompok orang tanpa ada paksaan. Sikap dan perilaku tersebut dapat menghasilkan kehidupan yang rukun dan damai demi hidup bersama yang lebih baik di antara umat yang berbeda agama.

Soloh sebagai nilai perdamaian pada kehidupan terkait dengan beberapa aspek yaitu: (1) kebersamaan. Kebersamaan merupakan suatu ikatan yang terbentuk karena rasa kekeluargaan pada orang lain. Kebersamaan dilihat melalui kemampuan menyelesaikan masalah secara gurêmi (bersama), dan menghargai perbedaan, (2) menghormati perbedaan. Menghormati perbedaan terkait kesadaran diri se-seorang menerima keberadaan orang lain. Dua hal terkait meng-hormati perbedaan, yaitu menerima keberadaan orang lain, dan menjaga perasaan orang lain, dan (3) sadar diri. Sadar diri terkait kesadaran seseorang akan nilai-nilai yang terdapat dalam dirinya. Sadar diri tidak hanya sekedar sadar akan posisi diri siswa sebagai seorang pelajar, 
namun juga sadar dirinya sebagai mahluk pribadi dan sosial yang potensi dan kelemahan yang dimiliki dalam dirinya sendiri. Sadar diri terkait dua hal, yaitu menghargai kebaikan orang lain, dan menjaga kenyamanan dalam kehidupan bersama.

6) Tetes

Tetes (partisipatif) terkandung dalam nilai onyaq (hati-hati, antisipatif) sebagai upaya mencegah terjadinya kerusakan lingkungan hidup. Tetes dikembangkan melalui menga-minger (berpikir terbukakritis) terhadap kondisi lingkungan hidup. Tetes terhadap lingkungan sebagai preferensi untuk hidup berkelanjutan dengan memelihara lingkungan agar tidak terjadi kerusakan. Lingkungan hidup yang lestari membawa kedamaian bagi penghuninya.

Leopold (1949) mengemukakan, manusia memiliki hubungan dengan kesehatan lingkungan sangat baik menciptakan peluang untuk membangun perdamaian. Carius (2006) mendeskripsikan lingkungan merupakan gambaran yang memiliki hubungan yang tidak pernah dapat dipisahkan dari keadilan sosial dan pendidikan perdamaian, karena lingkungan manusia dalam hubungannya dengan kesehatan lingkungan sangat baik untuk menciptakan peluang dalam membangun perdamaian. Lingkungan hidup memiliki mekanisme perdamaian, lingkungan memiliki kualitas, bahkan sangat berguna dan sesuai untuk membangun perdamaian.

Tetes sebagai nilai perdamaian dalam kehidupan di sekolah terkait: (1) upaya mencegah terjadinya kerusakan dan perawatan lingkungan hidup di sekolah agar tetap lestari, (2) upaya menjaga lingkungan hidup di sekolah dilakukan melalui kepedulian bersama, perbaikan, dan pelestarian lingkungan hidup, dan (3) mengembangkan wawasan ekologis pada setiap komponen sekolah sebagai upaya membangun kesadaran setiap warga sekolah (seperti kepala sekolah, guru-guru, pegawai, dan siswa) dengan prinsip-prinsip kelestarian alam yang termanisfestasikan melalui keyakinan, motivasi, perasaan, dan 
kebiasaan bersama dengan menjaga keseimbangan ekosistem sekolah yang dilakukan melalui perawatan bersama dan perawatan diri.

7) Saling Saduq

Saling saduq (saling percaya) terkandung dalam nilai lomboq (tulus, jujur, dan setia). Saling saduq berhubungan dengan perkataan, perbuatan, dan kebenaran yang disampaikan oleh seseorang pada orang lain saat berinteraksi dan berkomunikasi. Interaksi dan komunikasi tersebut menjadi pijakan seseorang dengan orang lain membangun keharmonisan di sekolah.

Hadjam \& Widhiarso (2003) menyatakan saling percaya adalah landasan membentuk hubungan yang terjadi jika kedua pihak saling percaya satu sama lain. Lawan dari rasa percaya adalah rasa curiga merupakan isyarat adanya disintegrasi. Rasa percaya merupakan penerimaan terhadap segala aspek kepribadian orang lain serta keunikannya. Rasa percaya dilandasi oleh pikiran positif dapat memunculkan prasangka baik terhadap orang lain. Selain prasangka baik, rasa percaya juga menurunkan perilaku seperti menerima orang lain, kemauan membina hubungan, dan berbagi.

Saling saduq dalam interaksi dan komunikasi menjadi landasan membangun perdamaian hidup di sekolah. Perdamaian tidak terwujud tanpa adanya saling saduq antara satu pihak dengan pihak yang lain, seperti guru harus saduq pada siswa, siswa saduq pada teman, dan lain-lain. Saling saduq dapat mengendalikan sifat-sifat kurang baik pada diri seorang, seperti lêkaq (bohong) dan ngakalang (curang). Saling saduq apabila tidak dilaksanakan dapat menimbulkan konflik antara siswa dengan guru dan siswa dengan siswa. Dampak yang terjadi berupa rasa benci, iri hati, tidak menyukai kepribadian guru, tidak menyukai mata pelajaran, mendiamkan, mengejek, dan menganggap diri 'lebih pintar'.

Saling saduq sebagai nilai perdamaian pada kehidupan di sekolah dimaknai sebagai: (1) rasa percaya atas perbuatan yang selaras antara apa yang ada diucapkan, dipikiran, dan diperbuat. Saling sadaq, 
terkait: (a) perkataan. Setiap perkataan seseorang harus selalu sesuai dengan pikiran dan perbuatan, atau dengan kata lain mengatakan sesuatu sesuai kenyataan dan melakukan sesuatu tersebut menurut semestinya, (b) perbuatan. Setiap perbuatan dilakukan oleh seseorang harus selaras dengan pikiran dan perkataannya, dan (c) kebenaran. Kebenaran memiliki makna menyatakan sesuatu seperti apa adanya, segala informasi yang disampaikan, pertanyaan yang diajukan, dan jawaban diberikan semata-mata kebenaran. Kebenaran dalam saling saduq dilandasi dua hal, yaitu semangat kemanusiaan dan ketulusan moral, (2) upaya mencegah prasangka negatif pada orang lain. Prasangka negatif, seperti rasa benci, iri hati, tidak suka, dan lainlainnya yang dapat mengarahkan seseorang berkonflik dengan orang lain, seperti konflik siswa dengan guru dan siswa dengan siswa, dan (3) menerima keberadaan orang lain, membina hubungan, berbagi, dan kesediaan membantu seseorang berkembang.

\section{8) Besemeton}

Besemeton (persaudaraan) merupakan nilai yang terkandung dalam nilai rapah (persatuan), yang artinya menganggap orang lain sebagai saudara. Saudara yang dimaksudkan di sini adalah seseorang dengan orang lain, tidak memiliki hubungan kekeluargaan atau tidak memiliki hubungan geneologis. Bêsêmêton pada kehidupan di sekolah terkait tiga hal, yaitu bêsêmêton atas dasar keyakinan, kemanusiaan, dan kebangsaan. Fondasi besemeton yakni saling menerima, sebagai salah satu pilar dalam menciptakan perdamaian di sekolah. Hadjam \& Widhiarso (2003) menyampaikan saling menerima adalah menerima orang lain, memiliki hak berpendapat, cita-cita, dan keinginan yang mungkin berbeda. Penerimaan terhadap perbedaan juga mencakup penerimaan pada orang lain yang memiliki latar belakang agama, etnis bangsa, dan ras yang berbeda sehingga tidak ada alasan untuk bertindak diskriminatif 
Bêsêmêton sebagai nilai perdamaian di sekolah dilaksanakan melalui saling menerima. Bêsêmêton terkait: (1) perilaku menganggap orang lain sebagai saudara. Perilaku ini diwujudkan melalui komunikasi yang baik menggunakan alus base (bahasa halus). Alus basê sebagai media komunikasi, seperti tidak menggunakan kata-kata yang kasar, kotor, dan jorok, karena perilaku damai terlihat dari ucapan sehari-hari di sekolah yang memberi manfaat bagi orang lain, dan (2) keakraban. Keakraban ditunjukkan dengan bêsapaq, bêsalam, dan bêsêlaman saat bertemu sebagai bentuk penghormatan secara tulus. Penghormatan ini untuk mencegah perilaku angkuh, sombong, dan tidak peduli pada sesama.

9) $R a^{\prime} i$

$R a^{\prime} i$ (rasa empati) sebagai salah satu yang terkandung dalam nilai rema (peduli sesama). Ra’i berkaitan langsung dengan mengerti, memahami, dan merasakan kesulitan yang dihadapi orang lain. Ra'i didasarkan manusia sebagai mahluk sosial tidak dapat dipisahkan dari orang lain. Tidak ada manusia yang tidak saling membutuhkan terutama dalam mengatasi kesulitan hidup yang dihadapi.

Samani \& Hariyanto (2012) memaknai empati terkait cara bertindak, berpartisipasi, dan ikut merasakan penderitaan dan kesedihan yang menimpa orang lain, sedangkan Hadjam \& Widhiarso (2003) mengartikan empati adalah menerima perspektif (frame of reference internal seseorang dengan ketepatan (accuracy) dan komponen emosional yang menyinggung pada sisi kemanusiaan. Hadjam \& Widhiarso (2003) juga menyatakan mengenai empati meliputi tiga hal, yaitu: (1) memahami persepsi pribadi orang lain dan merasa nyaman dengan persepsi itu, memahami persepsi pribadi orang lain berarti tahu bagaimana mereka memandang dunia dan menafsirkan segala sesuatu yang diterima, (2) menjadi sensitif, artinya dapat menetralisir dan menangani perasaan subjektif yang mengalir, dan (3) bergerak lembut tanpa memberikan penilaian (judgement) dengan keyakinan orang lain memiliki kesadaran yang unik (scarcely aware). 
Ra'i sebagai nilai perdamaian pada kehidupan di sekolah dimaknai sebagai perilaku mengenali dan berupaya mengetahui tanda-tanda (ciriciri) orang lain. Mengetahui terkait persepsi pribadi, sensitif terhadap keadaan orang lain, dan memahami perasaan orang lain. Mengenai: (1) persepsi pribadi sebagai proses menginterpretasikan sesuatu yang diterima dan diorganisasikan sehingga berpengaruh terhadap perilaku seseorang. Melalui sesuatu tersebut seseorang berbuat, walaupun sesuatu yang diterima sama, tetapi memiliki arti berbeda pada setiap orang. Persepsi pribadi terkait dua hal yaitu rasa terkait pada orang lain dan rasa berguna bagi orang lain, (2) sensitif terhadap keadaan orang lain, artinya terbangkit emosinya melihat keadaan orang lain. Sensitif terhadap keadaan orang lain dibiasakan pada siswa dengan memperhatikan orang lain dan kepekaan atas kebutuhan orang lain, dan (3) memahami perasaan orang sebagai upaya memahami kondisi yang dialaminya, seperti rasa iba atau belas kasihan, rela berkorban untuk orang lain, dan memiliki kemurahan hati.

10) Bedadayan

Bedadayan (kerja sama) terkandung di dalam nilai sangkepgundem (musyawarah). Bêdadayan merupakan suatu kegiatan yang dilakukan oleh dua orang atau lebih untuk saling membantu menyelesaikan suatu masalah. Bêdadayan dalam konteks lebih luas untuk merendahkan persaingan masing-masing orang atau kelompok yang berpotensi untuk saling menjatuhkan dan menghancurkan, maka diperlukan kompromi agar persaingan tersebut lebih bermanfaat dan saling menguntungkan.

Samani \& Hariyanto (2012) menyatakan kerja sama merupakan tindakan atau sikap mau bekerja sama dengan orang lain untuk mencapai tujuan bersama dan keuntungan bersama. Berbeda dengan Darmadji (2011) menyatakan kerja sama sebagai upaya memberi siswa kesempatan mengekspresikan ide-idenya, toleran, dan bersikap terbuka, serta guru memberi penjelasan tentang konsekuensi suatu tindakan terhadap orang lain dapat mengantisipasi kejadian-kejadian 
tindakan pada orang lain, anak didorong belajar alih peran (role taking) dan merespons secara empatik.

Bêdadayan dalam membangun perdamaian dalam kehidupan di sekolah terkait: (1) usaha yang dilakukan secara bersama untuk mencapai tujuan atau dengan kata lain sebagai usaha yang dilakukan beberapa orang siswa dalam suatu kelompok dengan melaksanakan tugas secara bersama sehingga dapat membawa keuntungan bersama juga. Dua hal terkait bêdadayan di sekolah, yaitu: (a) saling membutuhkan. Saling membutuhkan dalam hidup diperlukan perilaku dan perbuatan menghormati dan menghargai pilihan seseorang. Menghormati artinya setiap orang harus mengakui pilihan orang lain, karena setiap orang memiliki hak yang sama, dan menghargai pilihan orang lain, seperti hak berpendapat, dan (b) terbuka. Terbuka atau mênga artinya berpikir atau berbuat tidak hanya terbatas pada orang tertentu. Mênga dilakukan oleh siswa didasarkan atas sadar diri, komunikasi

yang efektif, dan pemikiran yang rasional; (2) upaya untuk meredam kecenderungan perilaku atau perbuatan individualis, egois, dan eksklusif pada diri seseorang, sehingga dapat meminimalisir konflik dan tindak kekerasan di kalangan siswa pada kehidupan sehari-hari, (3) upaya untuk mengatasi berbagai persoalan yang muncul dengan kesediaan seseorang menerima orang lain dan menutup munculnya perbedaan antarindividu, karena tanpa perbedaan berkembang konflik, seperti persaingan dalam mencapai tujuan.

\section{Simpulan}

Nilai kearifan lokal etnis Sasak bersumber dari tiga tradisi, yakni tradisi lisan, tulisan, dan aktivitas hidup sehari-hari masyarakat. Tradisi lisan berupa perangkat simbolik, seperti lêlakaq, wadi temah, paribasê, sêsênggak, sêsimbing, sênêpê, pênglingsir, dan waran atau tuaran. Tradisi tulisan, seperti naskah kuno antara lain naskah Kotaragama, Sari Manik, Jatiswara, babad Selaparang babad Lombok, babad Sakra Prudak Sina, naskah Asmaragama, dan naskah-naskah 
lainnya. Aktivitas sehari-hari masyarakat seperti prosesi kelahiran, perkawinan, kematian, dan lain-lain dalam wujud begawe atau rowah.

Nilai kearifan lokal etnis Sasak terdiri atas tiga lapisan, yakni nilai filosofis, penyangga, dan aplikatif atau intsrumental. Nilai filosofis berupa tindih, nilai penyangga berupa maliq dan merang, dan nilai aplikatif, seperti patut, patuh, pacu, solah, soleh, soloh, onyaq, dan lainlain merupakan realisasi dari nilai filosofis dan penyangga untuk membentuk kepribadin luhur seseorang.

Nilai-nilai kearifan lokal etnis Sasak menjadi kebutuhan setiap orang dalam proses menjadi pribadi dan mahluk sosial untuk menciptakan perdamaian hidup. Nilai-nilai tersebut terdiri atas 14 (empat belas) nilai, yaitu patut (benar, pantas), patuh (taat), pacu (kerja keras, sungguh-sungguh), solah (baik), soleh (religius), soloh (toleransi), onyaq (hati-hati, antisipatif), lomboq (jujur, tulus), rapah (persatuan), rêma (peduli sesama), rumie (kebersamaan), sangkep-gundêm (musyawarah), paut (sederhana), dan gêrasaq (ramah).

Nilai-nilai perdamaian dalam nilai-nilai kearifan lokal etnis Sasak pada kehidupan di sekolah terdiri atas 10 (sepuluh) nilai, yakni saling ajinang (saling menghormati-menghargai), tertip-terpi (tertib-teratur), teguq (tanggung jawab), solah perateq, (baik hati), soloh (toleransi, cinta damai), tetes (partisipatif), saling saduq (saling percaya), besemeton (persaudaraan), ra’i (empati), dan bedadayan (kerja sama).

Secara esensial, nilai-nilai perdamaian dan nilai-nilai kearifan lokal etnis Sasak berperan melahirkan dan mewujudkan kehidupan yang damai dalam kehidupan bermasyarakat. Nilai-nilai tersebut merupakan salah satu alternatif penyelesaian dan antisipasi konflik dan tindak kekerasan yang sering melibatkan siswa.

\section{Referensi}

Abebe, T.T., Gbesso, A., \& Nyawalo, P.A. (2006). Peace education in Africa. Addis Ababa: University for Peace. 
Amin, A., et al. (1977). Adat istiadat daerah Nusa Tenggara Barat. Jakarta: Projek Penelitian dan Pencatatan Kebudayaan daerah Depdikbud RI.

Arendt, H. (2003). Teori kekerasan. Yogyakarta: LPIP.

Arzaki, J. (2001). Kearifan budaya suku bangsa Sasak dalam menciptakan kehidupan yang harmonis, dalam Nilai-nilai agama dan kearifan budaya lokal: Suku bangsa Sasak dalam pluralisme kehidupan bermasyarakat. Mataram: Redam.

Asmara, G., Arba \& Maladi, Y., (2010). Penyelesaian konflik pertanahan berbasis nilai-nilai kearifan lokal di Nusa Tenggara Barat. Jurnal Mimbar Hukum, 22(1), 1-17.

Behera, S. K. (2013). Role of teacher in peace education. Samwaad: $e$ Journal, 2 (1), 16-87.

Bogdan, R.C. \& Biklen, S.K. (1992). Qualitative research for education: An introduction to theory and methods. Boston: Allyn and Bacon Inc.

Budiasmoro, Y. K. (2014). Membangun resiliensi kolektif masyarakat tradiisonal melalui pendidikan multikultural. Jurnal Pembangunan Pendidikan: Fondasi dan Aplikasi, 2(1), 26-32.

Carius, A. (2006). Environmental cooperation as an instrument of crisis prevention and peacebuilding: Conditions for success and constraints. Report commissioned by the German Federal Ministry for Economic Cooperation and Development.

Darmadji, A. (2011). Perilaku prososial vs kekerasan sosial: Sebuah tinjauan pendidikan sosial. Jurnal el-Tarbawi, 4(1), 27-34.

Denzin, N.K., \& Lincoln, Y.S. (Ed). (2005) Handbook of qualitative research. London: Sage Publications

Depdikbud. (1996). Pengungkapan nilai budaya naskah kuno Kotaragama. Jakarta: Departemen Pendidikan dan Kebudayaan Republik Indonesia.

DP2AP Kabupaten Lombok Timur, (2017/2018). Laporan kekerasan anak di Kabupaten Lombok Timur Provinsi Nusa Tenggara Barat.

Surabaya: Pustaka Eureka. (Edisi asli diterbitkan tahun 1996 oleh London: Sage Publications). 
. (1964). An Editorial. Journal of Peace Research, 1 (1), 1-4.

Fathurrahman, H. L. A. (2017). Kosmologi Sasak: Risalah inen paer. Mataram: Genius.

Flowers, N. (2000). The human rights education handbook. Minneapolis: University of Minnesota Human Rights Resource Center.

Fountain, S. (1999). Peace education in UNICEF. New York: Working Paper Education Section Programme Division UNICEF.

Hadjam, M. N. R., \& Widhiarso, W. (2003). Budaya damai dan anti kekerasan: Peace and anti violence. Jakarta: Dirjen Pendidikan Menengah Umum.

Hamdi, S. (2014). Nahdlatul Wathan di era reformasi: Agama, konflik komunal dan peta rekonsiliasi. Yogyakarta: Kurnia Kalam Semesta dengan Nawa Institute Kalimantan Timur.

Halstead, J. M. (Ed). (2005). Values and values education in school. In Values in education and education in values. London UK: Routledge Falmer Press.

Hasibuan, H. M. (2007). Manajemen sumber daya manusia. Jakarta: Bumi Aksara

Hendropuspito, D. (1989) Sosiologi sitematik. Yogyakarta: Kanisius.

Israil, et al. (2004). Dinamika pluralisme agama di Nusa Tenggara Barat. Jurnal Penelitian Keislaman, 1 (1), 1-16.

Kartadinata, S., et al. (2015). Pendidikan kedamaian. Bandung: Remaja Rosda Karya.

Kartawinata, A. M. (2011). Meretas kearifan lokal di tengah modernisasi dan tantangan pelestarian, dalam Nasrudin, dkk, Kearifan Lokal. Jakarta: Kementerian Kebudayaan dan Pariwisata Republik Indonesia.

Khalikin, A., \& Fathuri. (2016). Toleransi beragama di daerah rawan konflik. Jakarta: Badan Litbang dan Diklat Puslitbang Kehidupan Beragama Kementerian Agama RI.

Klare, M. T. (2002). Resource wars: The new landscape of global conflict. New York: Owl Books. 
Kumbara, A. A. A., (2008). Kunstruksi identitas orang sasak di Lombok Timur Nusa Tenggara Barat. Jurnal Humaniora, 20(3), 315-326.

Leopold, A.(1949). A sand county almanac. New York: Oxford University Press.

Mahyuni. (2004). Indirectness pada masyarakat Sasak: Fenomena metapor. Jurnal Linguistik, 22(1), 89-103.

Mezirow, J. (1997). Transformative learning: Theory to practice. In P. Cranton (Ed.) Transformative learning in action: Insights from practice: New directions for adult and continuing education. San Francisco: Jossey-Bass.

Miles, M. B., \& Huberman, A. M. (1994). Qualitative data analysis. London: Sage Publications.

Nimer, M. A. (2010). Nirkekerasan dan bina damai dalam Islam. Jakarta: Yayasan Abad Demokrasi.

Permana, C. E. (2010). Kearifan lokal masyarakat Baduy dalam mengatasi mitigasi bencana. Jakarta: Wedata Widya Sastra.

Rawls, J. (2006). Teori keadilan: Dasar-dasar filsafat politik untuk wewujudkan kesejahteraan dalam negara. (Terjemahan Uzair Fauzan dan Heru Prasetyo). Yogyakarta: Pustaka Pelajar. (Edisi asli diterbitkan pada tahun 1971 oleh Belknap Press).

Reardon, B. A. (2001). Education for a culture of peace in a gender perspective. Paris: UNESCO.

Rokeach, N. (1969). Beliefs attitude and values. San Franscisco: Jossey Bass

Samani, M., \& Hariyanto. (2012). Konsep dan model pendidikan karakter. Bandung: Rosda Karya.

Sukri, M. (2013). Fungsi naskah Prudak Sina dalam kehidupan masyarakat Sasak dalam perspektif nilai agama dan pendidikan. Jurnal Lentera Pendidikan, 16(1), 16-34.

Sulistiati. (1993). Babad Selaparang. Jakarta: Depdibud RI.

Sumpeno, W. (2012). Pengarusutamaan perdamaian: Konsep, kebijakan, dan strategi dalam program pembengunan daerah. Aceh: Badan Kepegawaian Pendidikan dan Pelatihan (BKPP)

Suparman, L. G. (1994). Babad Lombok. Jakarta: Depdikbud RI. 
(1994). Babad Sakra. Jakarta: Depdikbud RI.

Suprapto. (2013). Revitalisasi nilai-nilai kearifan lokal bagi upaya resolusi konflik. Jurnal Walisongo, 21(1), 19-38.

Syapruddin, H. L. (2009). Revitalisasi nilai-nilai budaya Sasak dalam pengamalan dan penegakannya. Makalah disampaikan pada Seminar Nasional di Universitas Mataram Nusa Tenggara Barat.

TPMD NTB. (1977). Monografi daerah Nusa Tenggara Barat. Jakarta: Depdikbud RI Direktorat Jenderal Kebudayaan.

Tumanggor, R. (2007). Pemberdayaan kearifan lokal memacu kesetaraan komunitas adat terpencil. Jurnal Penelitian dan Pengembangan Kesejahteraan Sosial, 12(1), 1-17.

Turay, T. M., \& English, L. M. (2008). Towards a global culture of peace: A transformative model of peace education. Journal of Transformative Education, 6(4), 286-301.

Trijono, L. (2009). Pembangunan perdamaian pasca-konflik di Indonesia. Jurnal Ilmu Sosial dan Ilmu Politik, 13(1), 48-70.

van der Meij, D., (2005). Berfikir positif masyarakat Sasak dalam manuskrip-manuskrip di Lombok, Nusa Tenggara Barat, dalam Bunga rampai budaya berpikir positif suku-suku bangsa. Jakarta: Departemen Kebudayaan dan Pariwisata RI bekerjasama dengan Asosiasi Tradisi Lisan (ATL).

Victorio, L. S. (2004). Global responsibility and local knowledge systems. A Millennium Assessment Paper Presented during the Bridging Scales and Epistemologies in the Millennium Ecosystem Assessment Conference held in Bibliotheca, Alexandria, in Egypt.

Wagiran. (2012). Pengembangan karakter berbasis kearifan lokal hamemayu hayuning bawana: Identifikasi nilai-nilai karakter berbasis budaya. Jurnal Pendidikan Karakter, 2(3), 329-339. 